\title{
O ACESSO À JUSTIÇA NOS SISTEMAS DE CRISE (ESTA- DO DE SÍTIO E DE DEFESA) NA CONSTITUIÇÃO DE 1988, EM PERSPECTIVA COMPARADA À DITADURA MILITAR BRASILEIRA (1964-1985)
}

\section{Carlos Eduardo Artiaga Paula* Felipe Pereira Maroubo**}

Sumário: 1 Introdução; 2 Acesso à justiça; 2.1 Concepção, análise histórica e problemas no acesso à justiça; 2.2 Estrutura e organização do Poder Judiciário; 2.3 Poder Judiciário, interpretação da Constituição e instrumentos processuais de acesso à justiça; 2.4 Poder Judiciário na ditadura militar brasileira; 3 Sistemas de crise: Estado de Sítio e de Defesa; 3.1 Concepção e análise dos dispositivos legais na Constituição de 1988; 3.2 Sistema de crise na ditadura militar brasileira (1964-1985); 3.3 Militarização da Justiça e seus efeitos no acesso à justiça; 4 Análise de documentos, depoimentos e reportagens jornalísticas referentes ao acesso à justiça na ditadura militar brasileira em perspectiva ao sistema de crise; 5 Considerações Finais.

Resumo: A temática do acesso à justiça passou a demandar maior aprofundamento e complexidade, de modo a compreender as novas perspectivas alcançadas pela democracia brasileira. A ditadura militar no Brasil representou uma mitigação no acesso à justiça dos cidadãos, em especial àqueles envolvidos com a luta político-ideológica de resistência às arbitrariedades cometidas em nome da segurança nacional. Diante dessa constatação, visa-se perquirir, em perspectiva comparada à ditadura militar brasileira

\footnotetext{
* Mestrando em Direito Público pela Universidade Federal de Uberlândia. Bacharel em Direito pela Universidade Federal de Uberlândia. Advogado atuante nas áreas cível e administrativo. Servidor público na Universidade Federal de Uberlândia. Especialista em Direito Processual Civil pela Universidade Anhanguera - Uniderp.

** Graduando em Direito pela Universidade Federal de Uberlândia. Bolsista do Programa Institucional de Bolsas de Iniciação Científica PIBIC/CNPq (2013-2014). Membro pesquisador discente da Rede Internacional de Estudos Schmittianos (RIES). Pesquisador do grupo de pesquisa e extensão "Democracia e Transição Política" (CNPq) da Universidade Federal de Uberlândia.
} 
(1964-1985), a possibilidade de assegurar os direitos fundamentais em face do abuso do poder estatal em períodos de sistema de crise no âmbito da Constituição de 1988. O material coletado, por intermédio de pesquisa bibliográfica e documental, está organizado em três capítulos de forma lógica, sistemática e teleológica. No primeiro capítulo, serão analisadas REFERÊNCIAS para destacar a evolução do acesso à justiça, deduzindo, em especial, a temática nos períodos de normalidade constitucional, tanto no período do liberalismo econômico quanto no estado social. O segundo passo consiste na análise da ditadura militar brasileira e dos sistemas de crise na Constituição de 1988. Por fim, serão analisadas as fontes documentais, notadamente, reportagens jornalísticas e depoimentos, à luz do arcabouço teórico construído nos dois primeiros capítulos, com perspectiva a avançar na discussão da possibilidade de um acesso à justiça eficaz a ponto de proteger os direitos do cidadão em situações de crise, considerando a concepção de acesso à ordem jurídica justa como um instrumento à disposição do cidadão para reivindicar a declaração e a efetivação de direitos.

Palavras-chave: Acesso à justiça. Poder Judiciário. Sistemas de crise. Ditadura militar e Redemocratização. Violações de direitos fundamentais. 


\section{Introdução}

O acesso à justiça, ou acesso à ordem jurídica justa, insurge como um instrumento à disposição do cidadão para reivindicar a declaração e a efetivação de direitos. A atual visão do Judiciário como um agente de transformação social e protetor dos direitos faz esquecer o recente passado no Brasil, em que havia dificuldades de acesso ao referido Poder e à justiça, embora essas disfunções perdurem até os dias atuais. A ditadura militar no Brasil, ocorrida entre 1964 e 1985, representou uma mitigação no acesso à justiça dos cidadãos, em especial àqueles envolvidos com a luta político-ideológica de resistência ao autoritarismo, à repressão e às arbitrariedades cometidas em nome da segurança nacional.

Diante dessa concisa constatação, visa-se, por meio deste estudo, perquirir, em perspectiva comparada à ditadura militar brasileira (19641985), se é possível, por meio do acesso à justiça, assegurar os direitos fundamentais em face do abuso do poder estatal em períodos de sistema de crise no âmbito da Constituição Federal de 1988.

Os objetivos específicos são inquirir a concepção, a construção histórica e os problemas no acesso à justiça. Compreender as peculiaridades do acesso à justiça durante a ditadura militar no Brasil (1964-1985), no tocante aos obstáculos e às limitações do acesso do cidadão. Averiguar o modo como os obstáculos de acessibilidade à justiça colaboravam com a agressão expressa aos direitos fundamentais, em especial, o de liberdade. Analisar a estrutura e organização do Judiciário e o modo como esse Poder interpreta a Constituição e os instrumentos jurídico-processuais no exercício de tal múnus. Relacionar o Judiciário e a ditadura militar brasileira, destacando a atuação daquele poder no regime de exceção. Investigar os sistemas de crise - o estado de sítio e o de defesa - na Constituição de 1988 e na ditadura militar, comparando-os. Observar o deslocamento de competência da Justiça Cível à Militar e as suas consequências no acesso à efetiva justiça. Comparar o acesso à justiça no período ditatorial e no democrático, com relação à restrição dos direitos fundamentais e da humanização da acessibilidade à justiça. Inquirir documentos, depoimentos e reportagens jornalísticas durante o período da ditadura militar, comparandoos mediante os critérios histórico, legislativo e judiciário.

Embora aparentemente conflitantes, serão utilizadas as pesquisas bibliográfica e documental, com predominância da primeira, que funcionará como apoio e referência na análise e no estudo das circunstâncias históricas, sociais, políticas, econômicas e jurídicas da ditadura e do ordenamento 
jurídico pós Constituição de 1988. As REFERÊNCIAS serão o ponto de partida para a argumentação a ser construída. O segundo tipo de pesquisa será empregado mediante análise de fontes documentais, notadamente, reportagens jornalísticas e depoimentos, tanto no contexto da ditadura, quanto no contexto da Constituição de 1988, relacionados à temática.

O material coletado será interpretado e organizado em três capítulos de forma lógica, sistemática e teleológica para conferir coerência e confiabilidade à argumentação. No primeiro capítulo, serão analisadas REFERÊNCIAS para conceituar e destacar a evolução do acesso à justiça, deduzindo, em especial, a temática nos períodos de normalidade constitucional, tanto no período do liberalismo econômico quanto no do estado social. O segundo passo consiste na análise da ditadura militar brasileira e dos sistemas de crise na Constituição de 1988. Por fim, serão analisadas as fontes documentais à luz do arcabouço teórico construído nos dois primeiros capítulos, com o objetivo de avançar na resposta ao questionamento da possibilidade de um acesso à justiça eficaz a ponto de proteger os direitos do cidadão em situações de crise.

Ao se reconhecer o atual contexto histórico como em crise, sobretudo no Brasil, caracterizado por severas crises econômicas, calamidades de grandes proporções da natureza e ações de grupos armados, visualiza-se a fragilidade da democracia e dos direitos fundamentais, face ao arbítrio do poder, em especial pela adesão à prática da tortura, com utilização ampliada, atingindo opositores ideológicos e políticos de indistintas classes, organizações e entidades sociais. Conforme Mattos (2003, p. 116), "a participação política de oposição passou a envolver o risco bastante palpável de prisão, tortura e morte".

Essa vulnerabilidade dos direitos do homem torna-se ainda mais sensível na instituição do estado de sítio e de defesa em que se autoriza legislativamente a restrição de direitos e das garantias fundamentais em prol da "segurança do Estado".

Todo esse arbítrio e uso indiscriminado do Poder é, atualmente, controlado e limitado, sobretudo pela atuação do Judiciário, visto como um dos principais defensores dos direitos do homem, já que, nos termos do art. $5^{\circ}$, inc. XXXV da $\mathrm{CF} / 88$, esse Poder não deve quedar-se inerte diante de uma lesão ou uma ameaça a direito. Por outro lado, a ditadura militar demonstrou que o acesso à justiça não foi respeitado, pois o Judiciário, cooptado pelo grupo dominante do Poder, agiu com uma postura predominantemente conservadora de manutenção do regime. 


\section{Acesso à justiça}

\subsection{Concepção, análise histórica e problemas no acesso à justiça}

Essencialmente relacionado aos problemas dos sistemas jurídicos, o acesso à justiça busca questionar a que preço e para quem o sistema funciona. Insurge como um instrumento à disposição do cidadão para reivindicar a declaração e a efetivação de direitos. No magistério de Batista (2010, p. 25) - na mesma linha de Bedaque (2003, p. 71) -, a finalidade do acesso à justiça é a tutela jurisdicional do Estado, de maneira que, uma vez fixado um direito, o cidadão possui previsão de dicção constitucional de que seus direitos serão tutelados.

Nos estados liberais burgueses, segundo a lição de Cappelletti (2002, p. 09), os procedimentos judiciais possuíam um viés formal e individualista, mas não com efetividade social, pois a justiça só poderia ser enfrentada por aqueles que pudessem cobrir os custos judiciais de suas demandas. Com o advento do estado social, denominado de welfarestate, o conceito de acesso à justiça modificou-se substancialmente. As ações e as relações jurisdicionais ganharam caráter coletivo e o Estado passou, em algumas circunstâncias, a assumir uma atuação positiva de assegurar aos cidadãos o gozo de alguns direitos sociais básicos, demonstrando situações de superação da visão formalista e dogmática do acesso à justiça. Nesse contexto, que permanece na contemporaneidade, o acesso à justiça possui uma visão ampla a ponto de influenciar e transformar diretamente os eventos sociais.

Essa consagração do acesso à justiça proporciona novo perfil ao Judiciário, não mais como um mero "boca da lei", conforme era no período das revoluções liberais burguesas do século XVIII, com a função precípua de empenhar-se em reproduzir literalmente as disposições normativas. Pelo contrário, o Judiciário está, cada vez mais, angariando apoio e prestígio junto à população que percebe, nesse Poder, o último instrumento de solução de seus problemas.

Nesse diapasão, o entendimento doutrinário majoritário é de que o acesso à justiça, além de proporcionar acesso aos tribunais, segundo Parosky (2006, p. 228), é "obter concretamente a tutela jurisdicional quando se tem razão", de modo a propiciar solução jurisdicional apropriada, efetiva e justa.

A concepção de acesso à justiça não se limita tão somente ao atendimento à população economicamente carente, mas envolve a redução 
de distâncias que separam o cidadão da efetiva tutela jurisdicional, o respeito ao devido processo legal, a duração razoável do processo, a otimização do sistema recursal e a participação eficiente das partes na relação estabelecida no tocante ao processo.

$\mathrm{O}$ direito fundamental ao acesso à justiça é também o mais básico dos direitos humanos, visto se apresentar, conforme leciona Canotilho (2003, p. 433 e 492), como direito de acesso aos tribunais e direito a uma solução jurídica de atos e relações jurídicas controvertidas. A isso deve-se assomar, a fim de tentar proporcionar um incremento das potencialidades da democracia, prazos razoáveis, garantias de independência e imparcialidade, de maneira a viabilizar o efetivo funcionamento do contraditório, para ampla participação das partes no oferecimento de provas e no conhecimento das provas da parte contrária e do valor e resultado de causas. Canotilho (2003, p. 433) menciona que

\begin{abstract}
significa isto que o direito à tutela jurisdicional efectiva se concretiza fundamentalmente através de um processo jurisdicional equitativo - dueprocess. [...] O direito ao processo equitativo está hoje positivamente consagrado no art. $20^{\circ}$ da CRP; no art. $6^{\circ}$ da Convenção Européia dos Direitos do Homem; no art. $14^{\circ}$ do Pacto Internacional Relativo aos Direitos Civis e Políticos e no art. $10^{\mathrm{a}}$ da Declaração Universal dos Direitos do Homem.
\end{abstract}

Parafraseando Kazuo Watanabe (1988, p. 128), para a concepção de acesso à justiça, designando-o como "direito de acesso à ordem jurídica justa", é elementar e intrínseco o direito à informação, à justiça organizada e composta por juízes imersos na realidade social e empenhados na meta de construção de uma ordem jurídica justa, à remoção dos obstáculos que impeçam o direito de ação e aos instrumentos processuais eficazes para a promoção da tutela de direitos do cidadão, substantivo do Estado Democrático de Direito.

Dos infortúnios do acesso à justiça, indaga-se, com suporte na doutrina de Batista (2010, p. 23), se o Poder Judiciário acolhe satisfatoriamente os interesses dos cidadãos e se o Judiciário e a sociedade civil puderam prescindir de uma relação consistente e de qualidade da prestação jurisdicional, sendo possível que os cidadãos pudessem se beneficiar da previsibilidade, certeza e segurança jurídicas, tanto na atualidade quanto no período de ditadura militar no Brasil, ressalvadas todas as peculiaridades dos liames temporais, pois, conforme propugna Batista:

A atual Carta Magna consentiu na ampliação dos direitos fundamentais situados na esfera pública que se estabeleceu como princípio democrático. Desse modo, $\mathrm{o}$ acesso à justiça proclama em termos constitucionais: a demanda refreada por direitos não constitucionalizados na época em que o Brasil viveu um governo autoritário. (2010, p. 43) 


\subsection{Estrutura e organização do Poder Judiciário}

O Poder Judiciário é alcunhado de "guardião da constituição" e "protetor dos direitos da minoria", ou seja, trata-se, na concepção de muitos, de um autêntico agente de modificações sociais. Horta leciona Horta que este é, na verdade, o

poder que assegura direitos, aplaca dissídios, compõe interesses, na diuturna aplicação da lei e de sua adaptação às mutáveis condições sociais, econômicas e políticas. É o Poder que enfrenta e deslinda dramas humanos, ouvindo queixas, reivindicações e protestos. É o Poder onde explode o ódio das vítimas e dos condenados, a revolta dos oprimidos, e a arrogância dos opressores. É o Poder que reclama de seus membros serenidade e bravura, paciência e desassombro, humildade e altivez, independência e compreensão. Poder tão próximo do dia-a-dia do Homem e da Sociedade, é natural o interesse dos cidadãos e das instituições pelo seu destino. (1987, p. 184)

A Constituição Federal de 1988 foi instituída sob o ideal do Estado Democrático de Direito, de modo que era elementar a consolidação de um sistema de governo plural e participativo, no qual houvesse a divisão de competências entre os três Poderes da União, a saber, os Poderes Legislativo, Executivo e Judiciário, que proporcionassem "freios e contrapesos" em prol dos interesses do Estado brasileiro.

O Poder Judiciário é designado pela Constituição para incumbir-se do papel de agente transformador da sociedade, capaz de influir nas decisões governamentais e nos desígnios da nação.

Em cotejo à Constituição de 1967, havia destacada prevalência substancial do Poder Executivo sobre os demais Poderes da República, em razão do robustecimento das competências de legislar, de iniciativa de leis, de aprovação de projetos governamentais, delegação legislativa, bem como, conforme Donato, "limitação de tempo para aprovação pelo Congresso" dos projetos em tramitação e "na restrição a emendas aos projetos governamentais e na faculdade, dada ao Presidente, de expedir decretos leis" (2006, p. 33).

Os governos arbitrários convulsionaram a sociedade brasileira, de modo a concorrer a um Judiciário brasileiro com "perfil de poder neutro, silencioso, discreto e pouco participativo" (DONATO, 2006, p. 14), originando uma falaciosa concepção de um Judiciário imune às pressões e clamores sociais, bem como às conjunturas políticas interna e externa.

A Constituição de 1988 construiu-se, pois, sob o ideal democrático e não poderia vitalizá-lo sem alterações substanciais na estrutura e organização do Poder Judiciário brasileiro. Dessa feita, foram criados 
cinco Tribunais Regionais Federais, bem como órgãos de duplo grau de jurisdição federal e gênese do Superior Tribunal de Justiça, incumbido de diversas competências originárias e recursais, anteriormente atribuídas ao Supremo Tribunal Federal e ao Tribunal Federal de Recursos.

A estrutura burocrática do Poder Judiciário vislumbra a construção doutrinária de identificação de três modelos de Judiciário constatáveis nos países ocidentais, quais sejam, segundo Zaffaroni (1995, p. 100), o empírico-primitivo, o tecnoburocrático e o democrático-contemporâneo.

Nos extremos, há os modelos empírico-primitivo e o democráticocontemporâneo. O primeiro caracteriza-se pela nomeação arbitrária dos juízes, que possuem baixo nível técnico e ideologia partidária marcadamente manifesta nas decisões, de modo que não é possível afirmar a independência das decisões e a robustez do controle de constitucionalidade. O segundo, por sua vez, qualifica-se como o mais aperfeiçoado, com os mais avançados mecanismos de seleção técnica de juízes, com juízes técnico-politizados, imparciais e independentes, cariz de permanência do controle de constitucionalidade, bem como fortalecimento da forma constitucional de Estado de Direito.

O Brasil, todavia, assume o espectro tecnoburocrático, visto que a seleção dos membros do Poder Judiciário, a rigor, ocorre por concurso público, com intuito de acautelar um elevado nível técnico dos futuros investidos. Não obstante o proeminente nível técnico dos magistrados de perfil carreirista, segundo Zaffaroni, "a independência do Judiciário é apenas externa, o controle de constitucionalidade tem baixo nível de incidência" (1995, p. 100).

Zaffaroni (1995, p. 100) menciona a superioridade desse modelo perante o empírico-primitivo, no entanto, destaca a indesejável carga de pragmatismo e exegética, de modo a contribuir para a construção de um Estado de Direito, em contexto político de estabilidade, porém, sentencia Donato, "mais legal que constitucional" (2006, p. 52). O estímulo ao carreirismo, caracterizado pelo agir no intuito de progredir rapidamente na carreira a todo custo, à organização vertical e a órgãos de cúpula essencialmente compostos por magistrados designados politicamente, é herança de interesses de uma sociedade voltada aos "pequenos litígios envolvendo proprietários e delinquência escassa e pouco complexa" (DONATO, 2006, p. 52).

A fim de elucidar a estrutura do Poder Judiciário, a Constituição Federal de 1988 distribuiu as tarefas entre os diversos órgãos que compõem o Poder Judiciário do país, a saber, os que têm dicção constitucional no art. 92: o Supremo Tribunal Federal; o Conselho Nacional de Justiça; o 
Superior Tribunal de Justiça; os Tribunais Regionais Federais e Juízes Federais; os Tribunais e Juízes do Trabalho; os Tribunais e Juízes Eleitorais; os Tribunais e Juízes Militares; os Tribunais e Juízes dos Estados e do Distrito Federal e Territórios.

É válido ressaltar que o Conselho Nacional de Justiça não é dotado de funções jurisdicionais, visto que é o órgão, no enleio do sistema judiciário brasileiro, com prerrogativas de controle do Poder Judiciário e daqueles que o integram. Foi admitido por força da disposição inserida na Constituição em 14 de junho de 2004, fixando como sede o Distrito Federal e atuação, reforça-se que não jurisdição, sobre todo o país. Sua competência precipuamente administrativa volta-se à defesa da autonomia do Poder Judiciário, à fiscalização de suas finanças, bem como zelo pela observância de normas disciplinares e correcionais por juízes e auxiliares da Justiça e do Estatuto da Magistratura.

Embora a jurisdição assuma caráter de indivisibilidade, há divisão de trabalho, comportando classificações: (I) pelo objeto, em Jurisdição Penal e Jurisdição Civil; (II) pelos organismos de jurisdição, em Jurisdição Especial, composta pelas justiças do trabalho, eleitoral e militar, com vistas também à jurisdição militar nas esferas federal e estadual, e Jurisdição Comum, subdivide-se em justiça estadual e federal, "cada uma com os seus juizados especiais para causas de menor complexidade ou reduzido potencial ofensivo". (GRINOVER, 1996, p. 175)

Conclui-se que, no tocante às tarefas jurisdicionais, há repartição horizontal de atribuições, no entanto, observados os diversos órgãos jurisdicionais isoladamente, há órgãos estruturados hierarquicamente, embora autônomos até mesmo no espectro administrativo, de maneira que, conclui Grinover (2013, p. 175), os critérios de distribuição de competências dependam da natureza da relação jurídica controvertida, da qualidade das pessoas figurantes como partes e em razão do lugar.

O Poder Judiciário, pois, revestiu-se de basilar importância para a sociedade brasileira, sendo necessária, ao sistema democrático, a exigência de condução dos propósitos do Estado com legalidade, impessoalidade, moralidade, publicidade e eficiência (art. 37, caput, CF/88). A crise do Poder Judiciário na recente ordem constitucional democrática, por conseguinte, é líquida e certa.

Adverte Moreira: 
mais precisamente no que respeita ao Poder Judiciário, ao contrário, pode-se inclusive afirmar que a nova ordem constitucional acabou colaborando, em certa medida, com o agravamento de uma situação de crise - compreendida enquanto atuação deficitária - que, de alguma forma, já vinha mesmo sendo desenhada há algum tempo e que ainda encontra-se pendente de um devido equacionamento tanto no que respeita à sua função instrumental, na composição formal dos conflitos, como no tocante a sua relevância político-institucional, enquanto poder do Estado. (2004, p. 65)

A Constituição de 1988 revigorou o Poder Judiciário, exigindolhe deveres intrínsecos ao exercício das atividades, a saber, eficiência, celeridade, participação, transparência e publicidade. No entanto, o Judiciário não estava preparado para acolher tão elevada demanda, ainda crescente.

\subsection{Poder Judiciário, interpretação da Constituição e instrumentos processuais de acesso à justiça}

O papel do Judiciário, atualmente, é de um efetivo transformador social que intervém nos Poderes Executivo e Legislativo ao exercer o controle de legalidade, razoabilidade e de proporcionalidade das normas. Logo, a função do Judiciário, sobretudo a dos Tribunais Superiores, é inerentemente política de interpretar e aplicar os princípios do Direito, notadamente os direitos fundamentais, altamente gerais e com elevada carga axiológica. Segundo Kildare Carvalho, "há, por isso mesmo, uma judicialização da política, das relações sociais, cenário em que passam a ter significativa importância as ações coletivas que asseguram a participação da sociabilidade no processo de aplicação do direito" (2004, p. 660).

Desse modo, o Poder Judiciário tem as prerrogativas de zelar pela Constituição Federal, pela aplicação correta das normas de direito brasileiro, com primazia de interpretação sistemática, com vistas a tutelar a democracia, os direitos fundamentais dos cidadãos brasileiros, titulares do poder e protagonistas de uma sociedade livre e justa, em face de abusos cometidos tanto por seus pares, bem como pelo Estado.

A lei possui espírito e pretensão, de modo que não se faz necessário infringir o ordenamento jurídico a fim de alcançar a justiça. Segundo Nalini (2005, p. 173), a interpelação do governante por qualquer cidadão que assume a figura de jurisdicionado é proporcionada pela cidadania. Além disso, está clarificado que as promessas concebidas por um Estado ineficaz e permeado por crises contínuas de governabilidade são pleiteadas 
do Poder Judiciário. Nesse sentido, segundo o autor, a sociedade brasileira tem cobrado dos magistrados uma visão em sintonia fina com uma "nova identidade do Poder Judiciário brasileiro", calcada na primazia da pretensão, sensatez e lógica razoável das normas em face do tradicional formalismo das leis, fruto de uma herança histórico cultural de excessivo apego positivista e privatista. (NALINI, 2005, p. 173)

Leciona Donato que "não se pode viver numa sociedade sem normas para assegurar os direitos; todavia, cabe ao Poder Judiciário preparar e encorajar os magistrados a conhecerem e aplicarem o espírito das normas" (2006, p. 70). Nesse sentido, Telles Júnior (2001, p. 367) encoraja a ideia de que a essencialidade da compreensão da interpretação das leis pelo Poder Judiciário está albergada na "justa e humana solução", atenta às condições afeitas a cada caso concreto, em detrimento do "rigor da lógica racional das leis", cujo império como conclusão lógica é falacioso.

A atividade jurisdicional é poder-dever do Estado, exercida pelo juiz devidamente investido em direito-função de a exercer, a fim de proferir decisões, em consonância com o espírito constitucional, de que o cidadão tem direito à ação e à resposta do Judiciário. A Emenda Constitucional $\mathrm{n}^{\circ}$ 45, de 30 de dezembro de 2004, atribuiu transparência ao Poder Judiciário, prestando credibilidade, sobretudo devido à publicização obrigatória das decisões administrativas. Aponta Donato, por conseguinte, que "os magistrados são as vigas da estrutura do Poder Judiciário à medida que dão vida a este Poder, não o deixando estagnar no arcaísmo de suas concepções, promovendo a paz na sociedade brasileira" (2006, p. 70).

A democratização e o aprimoramento do Judiciário dependem da conjunção das instituições sociais e, além disso, visto como poder político, deve ser capaz de garantir a democracia por meio das formas de participação popular e da adaptação às alterações pertinentes à tramitação mais célere e eficiente das ações judiciais. Renault propugna que:

além da reforma constitucional, é necessária a reforma da legislação processual para completá-la, cujos objetivos sejam penalizar a utilização desnecessária e procrastinatória do Poder Judiciário, restringir a utilização de algumas espécies de recursos e criar mecanismos de adequação das leis à evolução das relações sociais. (2005, p. 11)

O Poder Judiciário, por dicção constitucional, é guardião e intérprete da Constituição, responsável pela efetividade dos instrumentos constitucionais para concretização da Lei Maior, resguardando os direitos do cidadão perante os excessos e omissões do Estado. 
No tocante à garantia da melhor interpretação da Constituição e da concretização dos instrumentos processuais de acesso à justiça, adverte Barroso (2005, p. 67) que a Constituição Federal de 1988 separou as funções do Estado, viabilizando a aplicabilidade do sistema de freios e contrapesos, de modo a defender o povo de agressões estatais, por meio de instituições de proteção da intangibilidade da pessoa, como o Ministério Público.

Assim, para garantir a preservação dos mecanismos de controle e exercício probo das funções do Estado, a Constituição conferiu prerrogativas, imunidades e garantias aos agentes da sociedade, de modo que, afirma Donato:

o órgão do Ministério Público foi elevado a defensor dos direitos fundamentais e fiscal dos Poderes Públicos, tornando-se um dos princípios sustentadores da teoria dos freios e contrapesos. Também exercem controle nos poderes da União os Tribunais de Contas, que se destinam ao equilíbrio entre os poderes e a fiscalização destes. No âmbito do Poder Judiciário, existem as Corregedorias-Gerais que são órgãos estabelecidos nos Regimentos Internos dos Tribunais, encarregados de averiguar e punir as faltas funcionais ou disciplinares dos magistrados. [...] Vislumbrando a necessidade de um órgão de controle eficiente para o Poder Judiciário, bem como visando à democratização interna deste poder, a Emenda Constitucional ${ }^{\circ} 45$ instituiu o Conselho Nacional de Justiça (CNJ). (2006, p. 97)

Fabiana Spengler (2011, p. 58) oportunamente observa que os instrumentos processuais de acesso à justiça devem estar calcados em direitos fundamentais, sobretudo o due process of law, que reúne o devido processo legal e o contraditório processual, de maneira que se o acesso à justiça apresenta-se como reflexo da cultura de uma época, não é possível que a parte não se encontre em condições econômicas, culturais e sociais de ser ouvida, ou ainda, que, quando é ouvida, a resposta do jurisdicionado chegue tardiamente, a ponto de não mais solucionar o conflito que se põe em controvérsia.

Comparativamente aos regimes ditatoriais, como a ditadura militar implantada no Brasil no período de 1964-1985, o art. $5^{\circ}$, inc. LXXVIII, da Constituição Federal de 1988 representa elementar avanço ao proteger deontologicamente a todos, no âmbito judicial e administrativo, a duração razoável do processo e os meios que garantam a celeridade de sua tramitação. Assim, leciona Rodrigues que: 


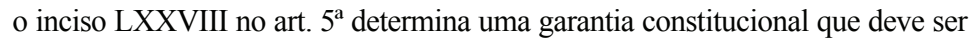
executada desde logo, sem o risco de esperar por ações legislativas posteriores que lhe venham a dar carga eficacial. O dispositivo em comento guarda especial importância em quatro aspectos: (1) torna obrigatória a prestação jurisdicional em um prazo razoável; (2) estabelece, ainda que de forma indireta, que prazo razoável é o prazo legal; (3) traz também a exigência de meios que garantam a celeridade processual; (4) por fim, introduz um conjunto de determinações relativas à organização do Poder Judiciário que, se implementadas de forma adequada, podem auxiliar decisivamente no cumprimento do mandamento constitucional. (2005, p. 288)

Bolzan de Morais assevera que as novas garantias constitucionais advêm da necessidade de conferir às normas constitucionais a pretensão de "reduzir desigualdades, erradicar a pobreza, fundar uma sociedade justa e solidária" (2008, p. 34), a fim de contemplar um projeto de sociedade que se comprometa com a dignidade humana e a integração da nação, visto que há primado do constitucionalismo social e democrático de direito.

Nas últimas décadas, o Judiciário demonstrou comportamento com escopo na contínua preocupação com os mecanismos de controle interno, transparência nos atos administrativos e cuidado, em curva crescente, com a dignidade humana, no entanto, as motivações da crise institucional alteraram-se. Isso, pois, na ditadura militar, o comportamento político, calcado em excessos, gerou uma enorme crise de credibilidade e transformou-se em fonte da qual emanaram injustiças. Nos últimos anos, segundo Faria (2005, p. 41-42), a crise institucional decorre da inércia comportamental em solucionar a atuação frente à: (i) consequência social da globalização econômica, especialmente quanto àqueles cujas condições materiais impedem o exercício de direitos básicos; e (ii) relativização da soberania, com o advento da globalização econômica. Enquanto gestor de conflitos em um cenário cambiante, o Poder Judiciário tem tido dificuldades de superar entendimentos tradicionais e sedimentados, enfrentando forte influência, como cita Faria, de fenômenos como a "judicialização da política", desvelando novos caminhos para a interpretação do direito.

\subsection{Poder Judiciário na ditadura militar brasileira}

A visão recente do Judiciário como um agente protetor dos direitos faz esquecer o recente passado no Brasil, em que o acesso ao referido Poder e à justiça demonstrou-se, comparativamente aos moldes do Estado Democrático de Direito, frágil e vulnerável. A ditadura militar no Brasil, ocorrida entre 1964 e 1985, representou uma mitigação no acesso à justiça aos cidadãos, em especial àqueles envolvidos com a luta político- 
ideológica de resistência ao autoritarismo, à repressão e às arbitrariedades cometidas em nome da segurança nacional.

Nesse contexto, a Constituição de 1967, com intuito de restringir a competência da Justiça Federal comum, incumbiu à Justiça Militar o processo e o julgamento dos crimes políticos compreendidos no Decreto-lei $\mathrm{n}^{\mathrm{o}} 314$, de 13 de março de 1967, que definiu os delitos contra a segurança nacional e a ordem política e social, preceito reiterado mais adiante na Emenda de 1969.

A Constituição de 1967, em previsão do art. 150, § 18, manteve, ainda, a soberania do júri, todavia, desprezou requisitos como o número ímpar de jurados, o sigilo das votações e a plenitude da defesa do acusado. No diploma de 1969, afinal, é expresso: "é mantida a instituição do júri, que terá competência no julgamento dos crimes dolosos contra a vida" (art. 153, §18), abrindo caminho, desta feita, à "gradual extinção do instituto, suprimida, como foi, a garantia constitucional da soberania de suas decisões" (NEQUETE, 1973, p. 96).

Uma enxurrada de medidas legislativas da ditadura buscou limitar sobremodo o Judiciário. $\mathrm{O}$ ato institucional $\mathrm{n}^{\circ} 01$ (AI 01), de nove de abril de 1964, reduziu drasticamente a intervenção do Judiciário, que não poderia apreciar os atos de suspensão das garantias de vitaliciedade e de estabilidade que extrapolassem as formalidades extrínsecas nem as hipóteses de suspensão dos direitos políticos (respectivamente art. $7^{\circ}, \S$ $4^{\circ}$ e art. 10).

O ato institucional $\mathrm{n}^{\circ} 02$, de 27 de outubro de 1965 - um dos que mais interviu no Judiciário -, criou a Justiça Federal, cuja principal competência cingia-se em apreciar e julgar os casos envolvendo a União (art. $6^{\circ}$ ), de maneira que os Juízes Federais seriam nomeados pelo Presidente da República (art. $6^{\circ}$ ). Deslocou-se para a competência da Justiça Militar o processamento e o julgamento dos crimes contra o Estado e contra a Ordem Política e Social, extinguindo-se, também, da apreciação judicial (art. 19): (i) os atos praticados pelo Comando Supremo da Revolução e pelo Governo Federal; e (ii) as resoluções das Assembleias Legislativas e Câmara de Vereadores que hajam cassado mandatos eletivos ou declarado o impedimento de Governadores, Deputados, Prefeitos ou Vereadores, a partir de 31 de março de 1964, até a promulgação do Ato.

Em seguida, com o ato institucional n..$^{\circ} 05$ (AI 05), de 13 de dezembro de 1968 , foi suspensa (art. $6^{\circ}$ ) a garantia do "habeas corpus, nos casos de crimes políticos, contra a segurança nacional, a ordem econômica e social e a economia popular" (art. 10). Além disso, deve-se destacar que, 
no AI 05, bem como em todos os outros atos institucionais, constava uma cláusula de exclusão da apreciação do Judiciário.

Em reforço ao AI 05, foram impostas medidas legislativas de grave punição jurídica aos opositores dos regimes. Com o Decreto-lei $n^{\circ} 477$, de 26 de fevereiro de 1969, tornou-se ilícito o movimento estudantil, definindo infrações a professores, alunos, funcionários ou empregados de estabelecimentos de ensino público ou particulares que se envolvessem ao referido movimento social. Com o AI 06, de cinco de setembro de 1969, foi instaurado o banimento do brasileiro que fosse declarado subversivo à segurança nacional e, com o Decreto-lei $\mathrm{n}^{\circ} 898$, de 29 de setembro de 1969, foram acentuadas as penas dos crimes de segurança nacional, permitindo a pena de morte e a prisão perpétua. Foram, ainda, aumentadas expressivamente as penas de reclusão. Com essa criminalização política, decorrente de filiação ideológica contrária ao regime, de modo que o número de recolhidos quase decuplicou (LEMOS, 2011, p. 06), em virtude da aplicação da Lei de Segurança Nacional por crimes de sequestro, assalto, terrorismo e atentado pessoal no período de 1964 a 1978.

Dessa forma, nos denominados "anos de Chumbo", Capellari (2001, p. 136) ressalta que o Poder Judiciário distanciou-se do papel de controlador e garantidor da tutela dos direitos fundamentais, expressos na Constituição Federal, e de responsável em certa medida pela efetividade das normas constitucionais.

\section{Sistemas de crise: Estado de Sítio e de Defesa}

\subsection{Concepção e análise dos dispositivos legais na Constituição de 1988}

Há, na Constituição de 1988, os sistemas de crise, notadamente estado de sítio e de defesa, que permitem a restrição de direitos em prol da segurança e sobrevivência do Estado. Junto ao sistema de crise, há um risco às próprias instituições democráticas, pois os governantes, ao concentrarem poderes, "se habituam às facilidades e por isso não querem mais tolerar o embaraço das formalidades. Formalidades sempre necessárias à salvaguarda da liberdade". (FERREIRA FILHO, 2007, p. 140)

O resguardo do Estado Democrático de Direito reclama uma ordem jurídica que preveja soluções para situações que desencadeiem ocasiões de anormalidade política e institucional, constituídas por fórmulas preventivas ou repressivas, a depender do grau de gravidade do momento. Concebe Silva (2004, p. 741) que "as contingências da crise visam a estabilização 
e a defesa da Constituição contra processos violentos de mudança ou perturbação da ordem constitucional, mas também a defesa do Estado quando a situação crítica derive de guerra". Ademais, o restabelecimento da normalidade constitucional dar-se-á por informação dos princípios da necessidade e da temporalidade ao conjunto coordenado de normas constitucionais.

Embora diversas expressões tenham sido eleitas como referência a essa proteção extraordinária do Estado, Canotilho propugna um significado a essa defesa da República, a saber:

previsão e delimitação normativo-constitucional de instituições e medidas necessárias para a defesa da ordem constitucional em caso de situação de anormalidade que, não podendo ser eliminadas ou combatidas pelos meios normais previstos na Constituição, exigem o recurso a meios excepcionais. (2003, p. 1085)

A legalidade assumida pela República Federativa do Brasil precipitase em normalidade, expressa na conduta que fundamenta as decisões dos cidadãos, no entanto, essa regra geral comporta variações, de modo que se definam situações de anormalidade cognitivamente previstas e passíveis de antecipação. É inerente ao Estado de Direito a tentativa de fixar normas aplicáveis em tempos de crise, visto ser basilar o espírito estatal e constitucional de restabelecimento da ordem e da normalidade quando os meios ordinários de contingência falharem.

A Constituição Federal de 1988 consagrou um novo direito constitucional de crise que objetivou, sob todas as formas, reagir em face dos espectros autoritários emanados pela Constituição de 1967 e Emenda de 1969, durante o período da ditadura militar no Brasil. A emergência adquiriu tratamento diferenciado no título V, da Constituição Federal, intitulado Da Defesa do Estado e das Instituições Democráticas, subdividido em três capítulos: Capítulo I Do Estado de Defesa e do Estado de Sítio (arts. 136 a 141); Capítulo II Das forças armadas (arts. 142 e 143); e Capítulo III Da Segurança Pública (art. 144).

A designação atribuída ao título $\mathrm{V}$ aponta, com clareza, que o regime de situações de exceção não significa suspensão da Constituição, mas, sim, um regime extraordinário incorporado na Constituição e válido às situações de anormalidade constitucional, conforme esclarece Canotilho (2003, p. 1186). Visto que a Defesa também se planifica no campo das instituições democráticas, deverá permanecer íntegra e em momento algum conduzir a arbitrariedades. 
Feito isso, a Constituição de 1988 consagrou um sistema de crise que prevê dois sistemas de resposta, sendo um mais brando no tocante ao grau de gravidade, o estado de defesa, e outro mais rigoroso a esse critério, o estado de sítio, que, no entendimento de Paula, "não se afasta muito do que adotou a Emenda n ${ }^{\circ} 11 / 78$ " (2008, p. 44).

$\mathrm{O}$ estado de defesa é uma medida excepcional inserida no rol do sistema constitucional de crise, apresentando expressa referência no art. 136 da Constituição. A instauração do estado de defesa é uma faculdade pessoal do Presidente da República, todavia, subsiste controle do Congresso Nacional, pois "é de sua competência exclusiva 'sustar os atos normativos do Poder Executivo que exorbitem do poder regulamentar ou dos limites de delegação legislativa', nos termos do art. 49, V, CR/88". (PAULA, 2008, p. 46)

É controvertida a situação que resta da discussão doutrinária sobre o caso de divergência entre a posição dos Conselhos da República e da Defesa Nacional, que devem ser ouvidos pelo Presidente da República antes da decretação do estado de defesa, e do Presidente. Em que pese a doutrina mais desenvolvida, Dantas (1989, p. 42) afirma que, pela análise do "espírito constitucional", havendo divergência entre a posição dos Conselhos e do Presidente da República, deve-se preponderar a decisão daqueles, funcionando ambos os Conselhos como verdadeiros "controles políticos".

Para conferir legitimidade ao estado de defesa, é indispensável a ocorrência de grave e iminente ameaça institucional, derivada de obra humana ou de calamidades que decorrem de ação devastadora da natureza. Assim, é possível justificar essa medida, por exemplo, em situações de calamidade natural provocada por ciclone, tornado, furacão, terremoto, maremoto, inundação, seca prolongada, ou ato derivado da ação humana, como peste, epidemia, fome e incêndio.

O decreto do estado de defesa obedecerá a três requisitos fundamentais: (i) tempo de duração fixado em trinta dias, prorrogáveis por uma única vez por igual período de tempo. Caso o Congresso Nacional rejeite a medida, o prazo não é absoluto, cessando os efeitos em virtude da aplicabilidade dos $\S \S 4^{\circ}$ e $5^{\circ}$ do art. 136, CF/88; (ii) fixação das áreas abrangidas, visto que o caput menciona que será decretado em "locais restritos e determinados"; (iii) não é possível que o Presidente exaspere os limites constitucionais estabelecidos, facultadas as medidas coercitivas a vigorarem a critério do Presidente da República. 
O estado de sítio é regulamentado pelo ordenamento jurídico brasileiro, utilizando-se o sistema rígido que prevê limites específicos das medidas utilizadas nesse estado, diferindo da lei marcial, típica construção do common law. Assim, o estado de sítio consiste na instauração de uma "legalidade extraordinária, por determinado tempo e em certa área, podendo se estender por todo território, objetivando preservar ou restaurar a normalidade constitucional". (PAULA, 2008, p. 57)

Essa medida excepcional é instaurada por ato pessoal do Presidente da República, que deve ouvir o Conselho da República e o Conselho de Defesa Nacional. A manifestação de ambos é obrigatória, caso contrário, a inconstitucionalidade da decretação da medida seria estabelecida. Solicitase a concordância prévia do Congresso Nacional, que deverá deliberar por maioria absoluta, após oitiva dos dois conselhos, restando o controle de legalidade exercido pelo Supremo Tribunal Federal.

A ocorrência do estado de sítio fica sujeita: (i) na hipótese do inciso I do art. 137, ao surgimento de comoção de grave repercussão nacional, de modo que se estabeleça profundo perigo às instituições democráticas, à tranquilidade e vida dos cidadãos, que têm seus direitos em iminente ameaça; (ii) na hipótese do inciso II do art. 137, à "declaração do estado de guerra ou resposta a agressão armada estrangeira”. (BRASIL, 2013)

O decreto do estado de sítio deverá ter como conteúdo material, compulsoriamente, sua duração máxima (hipótese do art. 137, I: o prazo poderá ser de trinta dias e sua prorrogação, de cada vez, só será possível por igual período), as normas necessárias para sua plena execução e as garantias constitucionais que ficarão temporariamente suspensas pela medida excepcional, consoante art. 138, caput. A decretação do estado de sítio deverá ter repercussão nacional. Todavia, não é necessário ter como área atingida todo o território nacional, visto que a Constituição designa "áreas abrangidas".

Paula rememora que:

Ivo Dantas critica a expressão "garantias fundamentais que ficarão suspensas", pois, por ser o Estado de sítio uma forma de legalidade especial rígida, somente poderão ser atingidas aquelas matérias constitucionalmente previstas. Assim, nenhuma garantia poderá ser "suspensa", pois os direitos individuais e coletivos, cujo exercício e gozo poderão ser assegurados pelas Garantias Constitucionais, tais como mandado de segurança, mandado de injunção, habeas corpus e habeas data, serão suspensos.(destaque nosso) (2008, p. 61) 
Por conseguinte, não obstante as medidas restritivas cabíveis aos estados de defesa e de sítio, subsiste o acesso à justiça como meio de defesa imanente do Estado de Direito, de maneira que "este controle político não excluirá o controle jurisdicional, isto com fundamento no art. $5^{\circ}, \mathrm{XXXV}$, que poderá ser exercido, durante o período de ou após a cessação de sua vigência" (DANTAS, 1989, p. 118).

Assim, abusos, arbitrariedades e ilegalidades podem, ainda que sob a vigência de qualquer uma dessas modalidades decorrentes do sistema de crise, ser reprimidos por intermédio de mandado de segurança e habeas corpus, garantias constitucionais processuais, visto que "a excepcionalidade da medida não possibilita a total supressão dos direitos e garantias individuais, e tampouco configura um salvo-conduto aos agentes políticos para total desrespeito à constituição e às leis" (MORAES, 2004, p. 671). Cabe ao Judiciário assegurar os direitos fundamentais de alta sensibilidade, a fim de preservar a dignidade da pessoa humana, que pressupõe, de uma maneira ou de outra, o acesso à ordem jurídica justa.

\subsection{Sistema de crise na ditadura militar brasileira (1964-1985)}

A Constituição de 1967 delineou o sistema de crise na ditadura militar brasileira (1964-1985), consagrando, em sua redação original, o estado de sítio, regulamentado no art. 152, para casos de: (i) grave perturbação ou ameaça de sua irrupção; (ii) guerra, período durante o qual estariam suspensas determinadas garantias constitucionais, a saber: (a) obrigação de residência em localidade determinada; (b) detenção em edifícios não destinados aos réus de crimes comuns; (c) busca e apreensão em domicílio; (d) suspensão da liberdade de reunião e de associação; (e) censura de correspondência, da imprensa, das telecomunicações e diversões públicas; (f) uso ou ocupação temporária de bens das autarquias, empresas públicas, sociedades de economia mista ou concessionárias de serviços públicos, assim como a suspensão do exercício do cargo, função ou emprego nas mesmas entidades.

Essa Constituição ainda permitiu a edição de lei regulamentar que dispusesse e autorizasse tomar outras medidas, "a fim de preservar a integridade e a independência do País, o livre funcionamento dos Poderes e a prática das instituições, quando gravemente ameaçados por fatores de subversão ou corrupção", consoante o art. 152, § 3º, CF/1967. Havia exclusividade da competência do Presidente da República, todavia, sujeitando o ato à apreciação do Congresso Nacional. 
No tocante ao prazo, estabeleceu-se o máximo de sessenta dias, podendo ser prorrogado por igual período com justificativa plausível do Presidente da República enviada ao Congresso Nacional. Em caso de recesso parlamentar, o Congresso será convocado imediatamente pelo Presidente do Senado Federal. Destaca-se a oitiva do Conselho de Segurança Nacional para a decretação do estado de sítio, no entanto, a decisão colegiada não vincula o Presidente da República.

Apenas se suspensas por voto secreto de dois terços dos membros da Casa legislativa a que pertencer o congressista, as imunidades parlamentares permanecerão. O controle pelo Poder Judiciário dos atos ilegais, a rigor, permanece íntegro.

Duas emendas foram basilares à alteração do estado de coisas do sistema constitucional de crise na ditadura militar brasileira, quais sejam: a emenda do Ato Institucional $\mathrm{n}^{0}$ 5, de 13 de dezembro de 1968, que editou a possibilidade de decretação do estado de sítio sem aprovação do Congresso Nacional ou de limitações outras previstas originalmente na Constituição de 1967; e, conforme observado por Paula (2008), a Emenda Constitucional $n^{\circ}$ 1, de 17 de outubro de 1969, em seu artigo 182, previu uma "suspensão transitória e parcial da Constituição, instaurando um estado de extraordinário, análogo ao estado de guerra da carta de 1937" (PAULA, 2008, p. 40-41), com a finalidade de dirimir a subversão e a corrupção.

\subsection{Militarização da Justiça e seus efeitos no acesso à justiça}

Com o golpe de 1964, o Judiciário, notadamente a Justiça Militar, foi usada como um meio político de institucionalização e legitimação da nova ordem política que se estabelecia, ou seja, segundo Da Silva (2007, p. 02), serviu como "instrumento de punição aos opositores do regime", mediante inquéritos e processos de crimes contra a segurança nacional. Em sentido contrário, Lemos (2004, p. 18) consigna a postura de alguns membros do Judiciário contra a ditadura. Assim, o Tribunal Militar passou a ter competência para julgar civis em crimes de ofensa à segurança do país ou às instituições militares, ou seja, a Justiça ganhou contornos de evidente instrumento de coerção jurídica. Esse momento de tensão generalizada, com cerceamento amplo do direito de defesa e da exiguidade do acesso democrático à justiça, é sintetizado por Lemos: 
não apresentava no currículo tais ligações, mas entendia de fazer oposição ao regime ditatorial, também sofria a ação repressiva, que ia da prisão, ao arrepio de todas as garantias legais, ao enquadramento em dispositivos jurídicos, velhos ou novos, interpretados de maneira a justificar o apenamento do suspeito. Entre a prisão e o julgamento, o acusado era submetido a interrogatórios sob todo tipo de violencia, inclusive torturas que, não raro, levavam à morte. (destaque nosso) (2004, p. 18)

Nesse contexto, o Judiciário e o Legislativo estavam submetidos à tutela do poder militar, concentrado nas mãos do Poder Executivo, de maneira que prevaleciam decisões meramente formalistas e com o objetivo de sustentar o regime. Por conseguinte, Lemos, atentamente, afirma que a "ênfase na legalidade, ainda que construída de forma casuística, e a consequente preservação do Judiciário em funcionamento, embora mutilado e tutelado pelo poder militar, se explicam pela própria natureza do regime ditatorial" (2004, p. 04). As possibilidades reais de acesso a uma justiça justa, democrática, plural, tanto sob o caráter formal como material, dos opositores do regime estavam restritas.

Assim, a ditadura militar brasileira investiu-se como um autêntico estado de exceção, compreendido como um estado destituído de qualquer conteúdo positivo, ou seja, um vazio de direito, uma vez que o ordenamento podia ser facilmente modificado conforme o bel arbítrio do Executivo. Essa assertiva é fácil de ser visualizada pelas características da própria ditadura, quais sejam: concentração de poderes de modo absoluto no Poder Executivo, excluindo a participação do Legislativo e do Judiciário; alta flexibilidade legislativa, pois o Executivo podia instituir qualquer norma que lhe conviesse, sem restrições formais ou de conteúdo, e sem o controle pelo Legislativo ou pelo Judiciário; restrição a direitos civis e políticos; criação de um vasto rol de crimes políticos com penas desproporcionais (como morte e prisão perpétua); intensa perseguição a opositores políticos, sendo que alguns foram levados à clandestinidade.

\section{Análise de documentos, depoimentos e reportagens jornalísti- cas referentes ao acesso à justiça na ditadura militar brasileira em perspectiva ao sistema de crise}

Este estudo estaria desprovido de repercussões práticas, se não desvelasse situações em que efetivamente houve violação, não apenas do direito fundamental ao acesso à justiça, mas também dos direitos fundamentais mais sensíveis, como à vida e à dignidade humana. 
Este capítulo visa analisar documentos referentes ao acesso à justiça na ditadura militar brasileira em perspectiva ao sistema de crise, a fim de assinalar, na dimensão ontológica dos desaparecidos, um drama agonizante de rostos sem feições e de figuras sem nome, sem memória e verdade oficial.

À concepção de acesso à justiça, designada como "direito de acesso à ordem jurídica justa", é elementar o direito à informação, a uma justiça organizada e composta por juízes imersos na realidade social e empenhados na meta de construção de uma ordem jurídica justa, que removam os obstáculos que impeçam o direito de ação e os instrumentos processuais eficazes para a promoção da tutela de direitos. Para tanto, este trabalho expõe, a partir de agora, uma análise de casos extraídos do Comitê Brasileiro pela Anistia, do Rio de Janeiro, em especial os estudos de 1979, atentamente analisados para arrebatar entrevistas, depoimentos e reportagens que demonstrem a relevância da manutenção da integridade da ordem jurídica democrática e justa pela via do acesso à justiça.

David Capistrano da Costa foi uma das vítimas da ditadura militar, foi declarado preso pelo presidente do STM, Hélio Leite, em 14 de Março de 1978 (CABRAL; LAPA, 1979, p. 60). O Ministro, respondendo a uma solicitação da representante da Anistia Internacional Patrícia Deerey, reconheceu a prisão de David pelo governo brasileiro, mas disse que ele foi liberado depois de uma semana. Não esclareceu, porém, a data, o local da prisão nem para onde ele foi levado. Como sempre, a fragilidade das afirmações do presidente do STM não convenceu ninguém, durante o governo de Geisel. Assim, há plenas demonstrações de arbitrariedades sancionatórias, com ausência de fundamentação para prisão, tal como privação do direito à informação para viabilizar o direito de ação do acusado.

Caso similar ocorreu com Hiram de Lima Pereira. Após inúmeras buscas pelo marido, a Sra. Célia apelou para o ministro da justiça, mediante uma carta em que "pedia providências para a localização do marido e relatava as coações, torturas e ameaças sofridas também pelas filhas da parte dos órgãos de repressão" (CABRAL; LAPA, 1979, p. 63). Pediu um julgamento justo das acusações que eventualmente lhe fossem impostas, consubstanciado nos princípios processuais do contraditório e ampla defesa. Segundo o relatório do Comitê Brasileiro de Anistia, à época: 
oficialmente, são poucas as citações do nome de Hiram desde sua prisão. A petição apresentada pelos advogados do desaparecido visando à obtenção de esclarecimentos sobre o motivo e as circunstâncias de sua prisão, com efeito, foi respondida pela Justiça Militar. Sob o título de Comunicação de prisão, o nome de Hiram aparece como indiciado sem irregularidade no despacho de 23 de abril de 1975, processo 433/75, da $2^{\text {a }}$ Auditoria da $2^{\text {a }}$ CJM de São Paulo (Diário da Justiça, 13/05/1975, p. 2480). A 20 de setembro de 1978, Hiram foi julgado à revelia pela $2^{\mathrm{a}}$ Auditoria da Marinha, a partir de quando também foram baldados os esforços para averiguar as circunstâncias do seu desaparecimento. (CABRAL; LAPA, 1979, p. 63)

No mesmo período, Jayme Amorim de Miranda, advogado, devidamente inscrito na OAB de Alagoas, segundo Cabral (1979, p. 66), foi preso e desapareceu, sem esclarecimentos pelo Estado de seu paradeiro ou circunstâncias em que o acontecimento se deu. Descreve Cabral que, ao noticiar à $\mathrm{OAB}$ de Maceió, o então presidente da Ordem, Dr. Ribeiro de Castro atentou-se para o caso:

Ninguém em Maceió, na $\mathrm{OAB}$, queria assumir a grave responsabilidade de imaginem - dizer que o associado era realmente associado, filiado à Ordem. Os estatutos da OAB proíbem que gestões sejam feitas sem o ponto de partida original - ou seja, a entidade de origem do associado. O jeito foi apelar. E o apelo foi entendido pelo Dr. Ribeiro de Castro que achou mais justo se tentar salvar uma vida a se ater a convencionalismos que a sombra do medo prejudica. $(1979$, p. 61)

Contudo, as tentativas de busca afogaram-se em inverdades sobre o paradeiro de Jayme (CABRAL; LAPA, 1979, p. 66-67). Por meio de reportagem do Jornal do Brasil, de 21 de setembro de 1978, veio a público, do ministro da Justiça, Armando Falcão, uma nota de desaparecidos políticos em fevereiro de 1975, em que dizia que David Capistrano estava na Tchecoslováquia e que João Massena havia sido solto em 1973, mas, sobre Itair José Veloso, nada foi revelado (CABRAL; LAPA, 1979, p. 72). Afirma a reportagem do Jornal do Brasil que:

os três desaparecidos foram incluídos no processo de julgamento de Luís Carlos Prestes e mais 60 pessoas acusadas de tentar reorganizar o PCB. O julgamento se deu na $2^{\mathrm{a}}$ Auditoria da Marinha nos dias 19 e 20 de setembro de 1978. Nessa sessão, o Conselho Permanente de Justiça da $2^{\text {a }}$ Auditoria da Marinha absolveu, por unanimidade, 11 dos acusados, considerou prescritas as penas de Prestes e mais 54 pessoas e mandou verificar os maus tratos denunciados pelo indiciado Dimas da Anunciação Perrin. Como outros, julgado a revel, Itair foi absolvido. Em sua defesa atuou o advogado Amilton Siqueira, Jornal do Brasil, 21/09/1978. (CABRAL; LAPA, 1979, p. 72, rodapé) 
Em relação a João Messena Neto, o Poder Judiciário mostrou-se absolutamente ineficiente para proteger os direitos de liberdade em sistema de crise. Precipuamente, em razão da forma como o processo é conduzido, ou seja, mediante a inércia, a verdade relativa e a não produção de provas. Desse modo, somente a defesa e a acusação poderiam solicitar a produção de provas, de forma que muitas delas podem ser recusadas ao arbítrio do juiz. Ainda que haja o livre convencimento motivado, o magistrado não pode se esquivar às provas constantes no processo, pois é vinculado a elas e à lei. Ademais, contam demasiadamente, no processo judicial, as manifestações dos agentes do poder público, que gozam de fé pública. Caso essas afirmações sejam contestadas, o suposto prejudicado deve realizar a prova. Não basta apresentar qualquer prova, ela precisa ser robusta e de exaustiva comprovação.

A família de João Massena Neto impetra um habeas-corpus no STM, n. 31.242, distribuído ao ministro Alcides Carneiro. Mas foi negado sob alegação de que Massena não se encontrava preso em nenhuma dependência militar. Já em 1975, sai uma nota do Ministro da Justiça, reafirmando que Massena não se achava detido em nenhum organismo oficial militar. (CABRAL; LAPA, 1979, p. 77)

Nesses casos, de João Messena e dos demais presos, desaparecidos e eventualmente mortos políticos, os órgãos do Judiciário, ou vinculados a ele, como o Ministério da Justiça e a $\mathrm{OAB}$, não tiveram a capacidade de investigar, apurar e amparar essas vítimas do regime. A proteção judiciária era encerrada mediante a inexistência de provas: os órgãos prisionais afirmavam que não havia aquele desaparecido político em sua organização, o que, ao valor da justiça, já bastava. A rigor, extinguia-se o processo por inexistência de provas, como ocorreu no caso acima, do habeas corpus no STM, $\mathrm{n}^{\circ}$ 31.242, distribuído ao ministro Alcides Carneiro. No entanto, "foi negado sob alegação de que Massena não se encontrava preso em nenhuma dependência militar". (CABRAL; LAPA, 1979, p. 77)

Sucedeu uma situação similar com o membro do Comitê Central do PCB, Orlando Bonfim Júnior, que, desde o ano de 1964, foi retirado do convívio com a família e a sociedade para entrar na clandestinidade, forçado pela situação política estabelecida no Brasil. Até os dias em que se produziram os relatórios do Comitê Brasileiro de Anistia do Rio de Janeiro, ninguém assumia sua prisão, foi quando a redação do Jornal $O$ Estado de São Paulo recebeu um telefonema anônimo informando da morte de Orlando Bonfim. Em síntese, no relatório analisado, Cabral descreve que: 
no dia 31 de outubro a família recebeu a informação, vinda através de amigos e de áreas militares, de que ele estava preso no DOI-CODI do Rio de Janeiro. Todos os contatos foram retomados. Novas cartas foram despachadas e a ABI, solicitada, enviou um pedido de informação ao comandante do I Exército, general Reynaldo Mello de Almeida. Mais três confirmações chegaram à família de que ele estava no Rio. Mas 11 dias depois o I Exército informava que ele não estava e nunca estivera lá. A resposta de outras áreas militares seria idêntica: ninguém assumia sua prisão. (1979, p. 79)

O apoio da Conferência Nacional dos Bispos do Brasil (CNBB) também se mostrou contundente para garantir, ou ao menos pressionar, o mínimo de pretensão de justiça, de modo que a esposa de Walter de Souza Ribeiro, militar reformado e jornalista, Adalcy Byrro Ribeiro procurou contato com a $\mathrm{OAB}$ e foi impetrado um habeas corpus, sem nenhum valor naquela época. Por intermédio da CNBB, recebeu a certeza do general Golbery de uma resposta no prazo máximo de um mês, mas a resposta ante o desaparecimento do marido não lhe foi dada. "O esfacelamento familiar foi completo, de modo que a família de Walter, em face da inércia do Poder Judiciário, sofreu a angústia, a revolta do desaparecimento e privações financeiras" (CABRAL; LAPA, 1979, p. 81), isso porque Adalcy tem direito a um soldo que não the é pago, no entanto, para recebê-lo, fazia-se necessário o atestado de óbito.

Em geral, grande parte das acusações estavam relacionadas a ideologias político-partidárias, como sucedeu com José Montenegro Lima, acusado pelos órgãos de segurança de ser militante do PCB, além de em 1963 ter sido eleito para a diretoria da União Nacional dos Estudantes Técnicos Industriais (UNETI), no Rio de Janeiro.

Afirma o relatório do Comitê Brasileiro pela Anistia do Rio de Janeiro:

Seus companheiros de cárcere, que se encontravam no DOI-CODI de São Paulo naquele setembro de 75 , afirmam que ele não chegou até lá. Teria sido levado diretamente para um dos sítios clandestinos da repressão, de onde não mais se teve notícias suas. (CABRAL; LAPA, 1979, p. 85)

Luiz Inácio Maranhão, ex-deputado pelo Rio Grande do Norte, cassado em 1964, professor universitário, advogado, jornalista, foi apontado como membro efetivo do Comitê Central do PCB em nota emitida pelo então Ministro da Justiça Armando Falcão. Por isso, foi arbitrariamente preso pelos órgãos de segurança. Odete Maranhão, esposa de Luiz Inácio, "constituiu como advogado Aldo Lins e Silva e peregrinou 'de delegacia em delegacia, de entidade em entidade, de autoridade a autoridade, tudo em vão"” (CABRAL; LAPA, 1979, p. 87). 
Mesmo com o apelo do deputado Thales Ramalho de pedido de julgamento de Inácio, a empreitada não obteve êxito. Além disso, o próprio ex-deputado reclamou direito a ser visitado por seu advogado, sua mulher e seus familiares, mas nada disso aconteceu. Em apertada síntese, Luiz Inácio apenas pretendia que fosse respeitada e reconhecida sua dignidade.

A ausência de respostas aos habeas corpus impetrados pelas famílias dos desaparecidos políticos constituiu um atentado ao efetivo acesso à justiça, pois embora pudessem ser impetrados, em momento algum as pretensões eram analisadas e as respostas proferidas ao jurisdicionado, conjuntura incompatível com o acesso à ordem jurídica verdadeiramente justa.

Esse cenário pode ser auferido na prisão de Rui Frazão Soares, pois muito embora Felícia Soares e Alice Frazão, sua mãe, tivessem contratado advogados em Recife, Fortaleza e no Rio, e fossem impetrados habeas corpus para sua localização, a atividade jurisdicional permaneceu inerte à lesão ou ameaça à lesão de direito. Sua esposa afirma, então, que: "Nenhuma notícia nos foi dada desde então" (CABRAL; LAPA, 1979, p. 93).

Em carta ao deputado Laerte Vieira, Alice Frazão, mãe do desaparecido político, revela sua aflição. Num trecho, diz ela:

\footnotetext{
Não sei qual a acusação que pesa sob meu filho, não sei que crime ele cometeu, e, principalmente - o que é particularmente doloroso para mim, como também para nossa família - é não saber onde ele se encontra, como está sendo tratado, se está vivo, se está morto, se está doente, sem assistência médica. (CABRAL; LAPA, 1979, p. 93)
}

Ilustra, também, as prisões, sequestros e assassinatos de desaparecidos políticos o sucedido com Mário Alves, jornalista, ex-diretor do jornal Novos Rumos e secretário geral do PCBR. Segundo testemunhas, o jornalista foi assassinado em 17 de julho de 1970, depois de uma longa noite de torturas no segundo andar do Pelotão de Investigações Criminais de Polícia do Exército do Rio de Janeiro. Em 16 de janeiro de 1970, Mário Alves foi sequestrado na rua e imediatamente conduzido para o quartel da PE (DOI-CODI do I Exército), onde foi torturado e morreu.

Segundo a esposa de Mário Alves, Dilma Borges Vieira:

Um determinado dia, no STM, me dirigi ao brigadeiro Correia de Mello e falei que queria saber o resultado do habeas corpus que eu havia impetrado. Aí, ele me perguntou: que é a senhora para estar tão emocionada? - Sou mulher dele, respondi; - Ah! Eu só atendi a senhora porque pensei que era a advogada. $\mathrm{O}$ Mário foi para Cuba e vai aparecer qualquer dia desses dando uma entrevista e falando mal do Brasil. (CABRAL; LAPA, 1979, p. 100) 
A falta de apuração é denominador comum nos casos envolvendo desaparecidos políticos privados de garantia de tutela de seus direitos fundamentais. Paulo Ribeiro Bastos e Sérgio Landulfo Furtado também integram essa extensa lista de protagonistas de casos misteriosos envolvendo o Poder Judiciário. Os dois jovens militantes foram presos e levados para o DOPS carioca, de onde, mais tarde, "foram transferidos para o DOI-CODI e torturados barbaramente" (CABRAL; LAPA, 1979, p. 126). Apesar de denúncias e provocações à justiça, baseado em caráter predominantemente familiar, em 1978, o ministro e general Rodrigo Otávio Jordão pede ao STM para apurar as possíveis mortes de Sérgio, Paulo e outros acusados, no entanto:

Apesar de sua insistência, nada foi apurado até hoje. Ambos protagonizaram casos misteriosos, porque todos os processos em que estiveram envolvidos correram à revelia. A Justiça Militar nunca explicou o paradeiro dos dois. (CABRAL; LAPA, 1979, p. 127)

Há, ainda, o caso paradigmático do ex-deputado federal por São Paulo, Rubens Paiva, que teve seus direitos políticos suspensos em 1964, pelo AI 01, sem acusação e instauração de nenhum inquérito policial militar ou processo penal.

Durante certo período, ninguém podia entrar nem sair da casa de Rubens Paiva. Três rapazes amigos da família apareceram, foram presos e levados para uma delegacia de polícia no Alto da Boa Vista. O telefone também ficou controlado: quem ligasse, ouviria a voz de Eunice, afirmando que Rubens viajara e que tudo estava bem. Armou-se uma cena de sequestro que se revelou uma farsa. Outrossim,

o caso teve grandes repercussões no Congresso Nacional, através de sucessivos pronunciamentos do então deputado Marcos Freire. O STM, por duas vezes, quando examinava os pedidos de habeas-corpus, insistiu para que a Procuradoria Militar apurasse o paradeiro do ex-deputado. Quando examinado pelo Conselho de Defesa dos Direitos da Pessoa Humana, em 1971, o caso dividiu opinião de seus membros. No mesmo conselho, em julho de 1971, com voto de Alfredo Buzaid (parente remoto de Rubens) a questão foi arquivada. (CABRAL; LAPA, 1979, p. 246)

Ademais, são inúmeros os casos por meio dos quais se examina que o Judiciário não protegeu de modo eficaz os direitos fundamentais, em especial os direitos e garantias individuais no âmbito da anormalidade constitucional implantada na circunstância da ditadura militar no Brasil, 
tão somente privilegiando uma classe dominante ou um grupo detentor do poder, deixando à revelia a sociedade brasileira, que padeceu indignada em face de afrontas constantes ao direito de ação e de acesso à justiça.

\section{Considerações Finais}

A motivação deste trabalho é, portanto, averiguar se o Judiciário protege de modo eficaz os direitos fundamentais, os direitos das minorias e assegura as garantias individuais no âmbito da Constituição Federal de 1988, ou se, em contrapartida, protege uma classe dominante ou um grupo detentor do poder, como ocorreu no período da ditadura.

Consoante o exposto no trabalho, em análise histórica das constituições brasileiras, verifica-se que o sistema de crises foi utilizado para reprimir divergências político-partidárias e não para a efetiva defesa do Estado, sobretudo quando, em estudo, está a Constituição de 1967, modificada pela Emenda Constitucional no 1 de 1969. Ademais, há uma predileção pelo estado de sítio, prevendo as condições aceitáveis para sua decretação. $\mathrm{Na}$ Constituição Federal de 1988, no Título V, há a previsão da "Defesa do Estado e das Instituições Democráticas". Por meio desse nome, inquire-se a preocupação do Constituinte na preservação das instituições do Estado e da ordem jurídica emanada pelo poder do povo. O sistema constitucional de crise brasileiro hodierno prevê, por conseguinte, os institutos do estado de defesa e estado de sítio.

Portanto, conclui-se que na Constituição da República Federativa do Brasil de 1988 busca-se superar as situações de crise para garantir a ordem democrática e não mais permitir o império do arbítrio do Estado, tal como foi utilizada a Constituição de 1967, e modificada em 1969 para atender aos arbítrios dos governos militares, de modo a dirimir drasticamente o acesso à justiça do jurisdicionado, em especial do perseguido pela ditadura militar; haja vista, hoje, que o Estado somente pode agir nos estritos termos e limites estabelecidos pela lei. Assim, caso os preceitos constitucionais não sejam observados, a medida é nula e seus executores serão responsabilizados civil e criminalmente.

A atual Constituição brasileira prescreve que nem todos os direitos e garantias fundamentais dos indivíduos deverão ser restringidos ou suspensos, mas tão somente aqueles em relação aos quais há expressa autorização constitucional. Ademais, o direito à vida, à dignidade humana, à honra e ao acesso à justiça, amplamente desenvolvido neste trabalho, deverão ser preservados, pois os sistemas constitucionais de crise não tratam de situação de arbítrio estatal, mas, sim, de legalidade extraordinária, minuciosamente regulamentada pela Constituição Federal de 1988, a "Constituição Cidadã". 
A fim de evitar abusos por parte do Estado, as lacunas legislativas deverão ser interpretadas de forma restritiva, sob uma análise histórica, sistemática e analítica. Os limites da necessidade, temporalidade e obediência irrestrita aos comandos constitucionais deverão ser examinados, pois a superação de grave crise de repercussão passa a não ser o único e basilar motivo de retorno à normalidade, mas a manutenção da integridade da ordem jurídica democrática e justa.

Dessa feita, em perspectiva comparada à ditadura militar brasileira (1964-1985), é possível, por meio do acesso à justiça, assegurar os direitos fundamentais em face do abuso do poder estatal em períodos de sistema de crise no âmbito da Constituição Federal de 1988, pois ficam imobilizados os direitos fundamentais de alta sensibilidade frente ao poder estatal, de modo a inviabilizar que situações de anormalidade provoquem injustiças, tais como as verificáveis no contexto histórico da ditadura militar brasileira, alheia à proteção ampla, integral e plena dos direitos fundamentais e da intangibilidade da pessoa humana.

\section{Access to justice in systems of crisis (State of Siege and Defen- se) in the 1988 Constitution in comparison with the Brazilian military dictatorship (1964-1985)}

Abstract: Access to justice has required greater depth and complexity in order to understand the new perspectives achieved by Brazilian democracy. The military dictatorship in Brazil meant a mitigation of citizens' access to justice, especially for those involved in the politicalideological resistance struggle against arbitrary acts carried out in the name of national security. Given this, this project aims to assert, in a comparative perspective to the Brazilian military dictatorship (19641985), the possibility to ensure fundamental rights in the context of governmental authority abuse in time crisis under the 1988 Constitution. The material collected by means of literature and documents, is organized into three chapters in a logical, systematic and teleological manner. In the first chapter, references will be analyzed to highlight the evolution of access to justice, deducting, in particular the issue in periods of constitutional normality, both in the period of economic liberalism as in the social state. The second step is the analysis of the Brazilian military dictatorship and systems of crisis in 1988 Constitution. Finally, in the last step, we analyze the documentary sources, 
notably, news stories and testimonies, in the light of the theoretical framework constructed in the first two chapters with a view to advance in answer to the question of the possibility of having an effective access to justice point protect the rights of citizens in crisis situations, the light of the concept of access to fair legal system as an instrument at the disposal of citizens to claim the declaration and to enforee.

Keywords: Access to justice. Judiciary. Systems crisis. Military dictatorship and Redemocratization. Violations of fundamental rights.

\section{REFERÊNCIAS}

BARROSO, Luís Roberto. Constitucionalidade e legitimidade da criação do Conselho Nacional de Justiça. In: RENAULT, Sérgio Rabello Tamm; BOTTINI, Pierpaolo (Coord.). Reforma do Judiciário. São Paulo: Saraiva, 2005. p. 53-85.

BATISTA, Keila Rodrigues. Acesso à justiça: Instrumentos viabilizadores. São Paulo: Letras Jurídicas, 2010.

BEDAQUE, José Roberto dos Santos. Tutela cautelar e tutela antecipada: tutelas sumárias e de urgência. São Paulo: Malheiros, 2003.

BRASIL. Constituição (1988). Disponível em: <http://www.planalto.gov. br/ccivil_03/constituicao/constituicao.htm>. Acesso em: 9 ago. 2013.

CABRAL, Reinaldo; LAPA, Ronaldo (Org.). Desaparecidos políticos: prisões, sequestros, assassinatos. Rio de Janeiro: Edições Opção, 1979. v. 2.

CANOTILHO, José Joaquim Gomes. Direito Constitucional e Teoria da Constituição. 7. ed. Coimbra: Almedina, 2003.

CAPELLARI, Eduardo. A crise do Poder Judiciário no contexto da modernidade: a necessidade de uma definição conceitual. Revista de Informação Legislativa, Brasília, v. 38, n. 152, p. 135-149, out./dez. 2001. Disponível em: <http://www2.senado.leg.br/bdsf/item/id/727> Acesso em: 29 abr. 2013. 
CAPPELLETTI, Mauro; GARTH, Bryant. Acesso à justiça. Trad. Ellen Gracie Northfleet. Porto Alegre: Sérgio Antônio Fabris, 2002.

DANTAS, Ivo. Da defesa do estado e das instituições democráticas na nova constituição. Rio de Janeiro: Aide, 1989.

DONATO, Verônica Chaves Carneiro. O Poder Judiciário no Brasil: estrutura, críticas e controle. 2006. 107 f. Dissertação (Mestrado em Direito Constitucional) - Fundação Edson Queiroz, Universidade de Fortaleza, Fortaleza, 2006.

FERREIRA FILHO, Manoel Gonçalves. Estado de direito e constituição. 4. ed. São Paulo: Saraiva, 2007.

GRINOVER, Ada Pellegrini. Teoria geral do processo. 12. ed. São Paulo: Malheiros, 1996.

HORTA, Raul Machado. Unidade e dualidade na magistratura. Revista de informação legislativa, Brasília, v. 24, n. 96, p. 179-188, out./ dez. 1987. Disponível em: <http://www2.senado.gov.br/bdsf/bitstream/ id/181814/1/000434306.pdf $>$. Acesso em: 14 mar. 2013.

LEMOS, Renato. Justiça fardada: o general Peri Bevilaqua no Superior Tribunal Militar (1965-1969). In: SEMINÁRIO 1964-2004: 40 ANOS DO GOLPE, DITADURA MILITAR E RESISTÊNCIA NO BRASIL, 2004, Rio de Janeiro. Anais ... UFRJ, UFF, CPDOC e APERJ. Rio de Janeiro: 7Letras; FAPERJ, 2004.

. Ditadura militar, violência política e anistia. 23 jul. 2011. Disponível em: $<$ http://www.lemp.historia.ufrj.br/imagens/textos/Ditadura_militar_violencia_politica_e_anistia.pdf $>$. Acesso em: 13 mar. 2013.

. Poder militar e poder Judiciário. In: CASTRO, Celso; IZECKSOHN, Vítor; KRAAY, Hendrick (Org.). Nova história militar brasileira. Rio de Janeiro: Fundação Getúlio Vargas; Bom Texto, 2004.

. Ditadura militar, violência política e anistia. 23 jul. 2011. Disponível em: $<$ http://www.lemp.historia.ufrj.br/imagens/textos/Ditadura_militar_violencia_politica_e_anistia.pdf $>$. Acesso em: 13 mar. 2013. 
MATTOS, Marco Aurélio Vannucchi L.; SWENSSON JUNIOR, Walter Cruz. Contra os inimigos da ordem: a repressão política da ditadura mili$\operatorname{tar}$ (1964-1985). Rio de Janeiro: DP\&A, 2003. 116 p.

MORAES, Alexandre de. Direito Constitucional. 15. ed. São Paulo: Atlas, 2004.

MORAIS, José Luis Bolzan de; SPENGLER, Fabiana Marion. Mediação e arbitragem: alternativas à jurisdição. 2. ed. Porto Alegre: Livraria do Advogado, 2008.

NALINI, José Renato. A democratização da administração dos tribunais. In: RENAULT, Sérgio Rabello Tamm; BOTTINI, Pierpaolo (Coord.). Reforma do Judiciário. São Paulo: Saraiva, 2005. p. 159-184.

NEQUETE, Lenine. O Poder Judiciário no Brasil a partir da Independência. Porto Alegre: Sulina, 1973.

PAULA, Carlos Eduardo Artiaga. Sistemas Constitucionais de Crise na Constituição da República Federativa do Brasil de 1988. 2008. Monografia de conclusão de curso de Direito - Faculdade de Direito Prof. Jacy de Assis, Universidade Federal de Uberlândia, Uberlândia, 2008.

PAROSKY, Mauro Vasni. Do direito fundamental de acesso à justiça.

Revista Scientia Iuris do Programa de Mestrado em Direito Negocial da UEL, Londrina, v. 10, p. 225-242, 2006. Disponível em: <http://www.uel.br/revistas/uel/index.php/iuris/article/view/\%204132>. Acesso em: 29 abr. 2013.

RENAULT, Sérgio Rabello Tamm. Reforma do poder judiciário. São Paulo: Saraiva, 2005.

SILVA, Ângela Moreira Domingues da. Ditadura militar e justiça castrense no Brasil: espaço de legitimação política e de contradições (1964-1985). ago. 2007. Disponível em: <http://www.arqanalagoa. ufscar.br/abed/Integra/Angela\%20Moreira\%2013-08-07.pdf $>$. Acesso em: 20 mar. 2013. 
SILVA, A. M; PINHEIRO, M. S. F; FRANÇA, M. N. Guia para normalização de trabalhos técnico-científicos: projetos de pesquisa, trabalhos acadêmicos, dissertações e teses. 5. ed. Uberlândia: Edufu, 2005 .

SILVA, José Afonso da. Curso de Direito Constitucional Positivo. 23. ed. São Paulo: Malheiros, 2004.

SPENGLER, Fabiana; NETO, Theobaldo. O acesso à justiça como "direito humano básico" e a crise da jurisdição no Brasil. Revista Scientia Iuris do Programa de Mestrado em Direito Negocial da UEL, Londrina, v. 15, n. 2, p. 53-74, dez. 2011.

TELLES JÚNIOR, Goffredo. Iniciação na Ciência do Direito. São Paulo: Saraiva, 2001.

ZAFFARONI, Eugenio Raúl. Poder Judiciário: crise, acertos e desacertos. São Paulo: Revista dos Tribunais, 1995.

WATANABE, Kazuo. Acesso à justiça e sociedade moderna. In: GRINOVER, Ada Pellegrini; DINAMARCO, Cândido Rangel; WATANABE, Kazuo (Coord.). Participação e processo. São Paulo: Revista dos Tribunais, 1988.

Recebido: outubro/2013. Aprovado: dezembro/2013. 